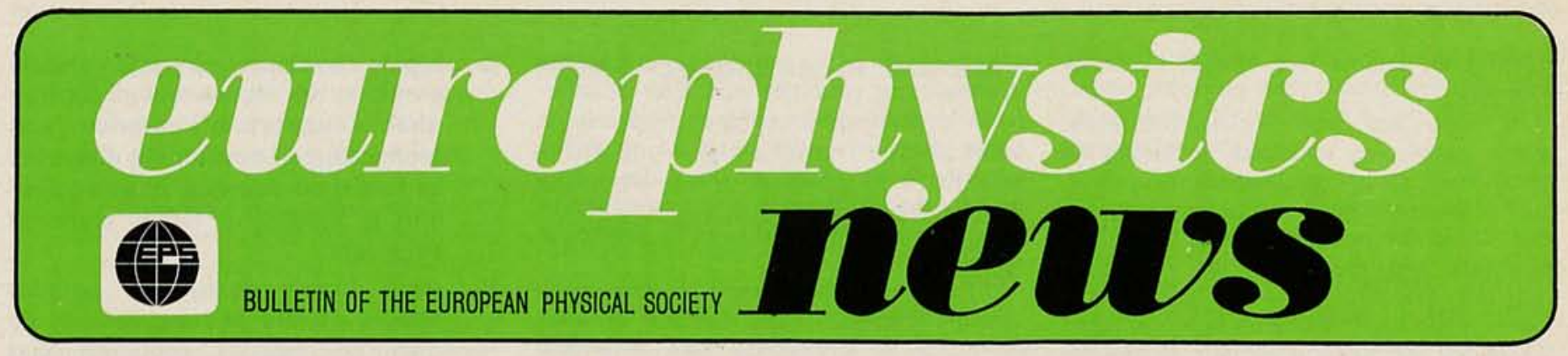

\section{Viewpoint}

\section{Physics for the third world}

Much more than the European public, the nations of the third world look to science and technology as the key to economic and social development. Since physics-based technologies contribute so much to the prosperity of developed countries, rapid improvement of physics in the third world should now be a central concern of physicists and their institutions everywhere. In the article on the World Plan of Action, it is proposed by a UN Advisory Committee that the governments in developed countries should increase their research and development budgets by $5 \%$ - to be devoted to science relevant to third world problems. Such a directed increase would only bring results if scientists in developed countries were prepared to accept social responsibility for their colleagues from developing countries. Of course, there are already many links by which physicists from developing countries train in the academic centres of Europe. However, if these physicists return to their countries of origin (and many do not), they are in danger of isolation, unless their European colleagues deliberately maintain contact. Further physics centres in Europe might well consider the model of the Fellowship scheme for senior physicists which operates at the International Centre for Theoretical Physics at Trieste. Although such a scheme of short visits in five successive years might not seem appropriate for experimental physics, personal exchanges would inevitably lead to better contacts when the Fellows went back to their own laboratories. Through such schemes, European physicists and institutions could be led to respond to the challenge of work for developing countries, especially if the many interesting physics problems related to third world development could be tackled with adequate and appropriate facilities.

\title{
World Plan of Action for the application of science and technology for developing countries
}

Nothing less than accelerated world development through the application of science and technology was the goal set by the United Nations in the World Plan of Action ${ }^{1}$, published in 1971. This thought-provoking and comprehensive programme of concerted action, at the national and international level, was the main result of six years' work by the UN Advisory Committee on the Application of Science and Technology to Development. The UN Advisory Committee maintains that two requirements need to be fulfilled before the World Plan of Action can be successfully implemented

(a) the full backing of the United Nations machinery, international agencies and national governments to promote and finance the activities :

(b) the mobilization of the international scientific community to effect the proposals.

With the recent welcome given to the World Plan of Action by the principal organ of the United Nations in this field, the Economic and Social Council, the first requirement is well on the way to being met. So, the UN Advisory Committee is increasingly turning its attention to the motivation and orientation of individual scientists towards carrying out the programmes.

To quote the World Plan of Action (page 49) :

'The potential contribution of the international scientific community through governmental organizations and in the freer atmosphere of universities and research institutes should also be emphasized. The United Nations has made all too little progress towards mobilizing the interest and support of the universities and centres of learning, or of the main body of scientists throughout the world. Yet the world scientific community constitutes a valuable fund of idealism and brainpower, which can make a great contribution to world development and, indeed, to world peace, provided that ways can be found of offering scientists opportunities for practical participation in the Second United Nations Development Decade.'

\section{Background}

The World Plan of Action is based upon the following premises (page 45):

(a) The scientific approach offers the best hope for assisting the developing nations to speed up the process of their all-round development :

(b) This hope can only be fulfilled if the investment of resources in scientific and technological research and application is undertaken in a spirit of true co-operation, with due regard to the differences in the circumstances of different countries. and on a sufficiently large scale. In each country, it must be based on a national science policy ;

(c) The growing gap between developed and developing countries in the amount of research and application and in their levels of technology is one of the major factors in the increasing discrepancy in living standards :

(d) The process of world development consists partly (but not wholly) in bringing about a wider sharing of its benefits not only through trade and aid but also through the transfer of modern technology to the developing countries :

(e) Obstacles hinder this transfer to the developing countries. They derive from the absence of an adequate international system for the selection and flow of scientific and technical information to developing countries; they also raise specific problems

\section{Contents}

Viewpoint . . . . . . . 1

World Plan of Action . . . 1

Letter to the Editor . . . 3

Nobel Prize in Physics 19724

Physicist's Conception of

Nature . . . . . . . . 5

EPS General Assembly . . 6

Trends in Physics . . . . 6

Shadows of Bliss . . . . 7

Meetings . . . . . . 8 
relating to patents and similar industrial property :

(f) There are also serious obstacles within developing countries, including an insufficient supply of trained manpower, lack of the institutions and of the resources that would be needed to train their own scientists and technicians on the scale required, the attraction of the professiona career opportunities offered in more highly developed countries, a social and psychological climate that is not everywhere favourable to the adoption of innovations in methods of production, and a scarcity of the economic resources that are required to make such application practically, as distinct from theoretically, possible.

As a popular exposition of the background to these premises, The Great Experiment ${ }^{2}$ is very readable.

In an article $^{3}$ in Physics Today, M.J. Moravcsik identifies the two main problems which can be solved by physicists in developed countries - scientific isolation and lack of trained manpower. He makes out a very strong case, and recommends that societies such as the American Physical Society and the European Physical Society should have committees charged to catalyze and coordinate scientific assistance programmes in their communities. Also, a member of the UN Advisory Committee, Professor $\mathrm{H}$. Bunting (Reading University, U.K.), has suggested that societies such as EPS should have correspondents to ensure appropriate international contacts and communications at the professional level.

\section{Recommendations and targets}

In the World Plan of Action, two particular recommendations are made to the international scientific community (page 50)

'(a) An extension and strengthening of the well-tried practice of establishing $\mathrm{co}$ operative links betwen universities, re- search institutes or individual laboratories in developed countries and their counterparts in developing countries. There is no better way of building up to scientific maturity in an institution in a developing country than to develop a live co-operative bond with a counterpart in some developed country ;

(b) Measures to promote greater interchange of scientists and contacts between scientists of developing and developed countries. National academies of science, universities and foundations should send eminent men of science to work for a period of time in developing countries. Encouragement should be given also to younger scientists to carry on postgraduate work in developing countries, and distinguished service in developing countries should be given public recognition. The removal of existing obstacles to such movement (and the risks they introduce into a young scientist's career) should be accepted as a task for the national academies or other competent authorities. Universities and institutes in developed countries should increase the facilities for promising young scientists from developing countries to spend frequent short periods at such centres while retaining their appointments in their own countries. Such measures would contribute to a reduction in the "brain drain" from developing countries. Examples of what is needed are the proposed extension of the associate fellowship scheme already operating at the International Centre for Theoretical Physics at Trieste, and the activities of the United Nations Educational, Scientific and Cultural Organization (UNESCO) in the same sphere.'

The most controversial part of the World Plan of Action was the section outlining three quantified targets :

I the objective for developing countries should be to attain by 1980 a minimum level of $1 \%$ of Gross National Products for research and development, and scientific and technological services, of which half should be on research and experimental development proper ;
II highly developed countries should continue to increase aid for the direct support of science and technology in developing courtries to reach an average level equivalent to $0.05 \%$ of Gross National Products ;

III each highly developed country should devote at least $5 \%$ of its own non-military research and development expenditures to research for developing countries by 1980 .

Some policy makers have argued that target III is overambitious. However, the UN Advisory Committee has evidence that $30 \%$ of research and development expenditures in highly developed countries is devoted to military research - approximately $\$ 18,000$ million - so that target III could be met by a small and gradual transfer to civil research for developing countries.

The UN Advisory Committe also concluded that target III, although ambitious, will do no more than meet the growing awareness of social responsibility towards developing countries within the scientific communities of developed countries. Another recommendation is that the international scientific community should be mobilized (page 87)

'Within the advanced countries it would help to achieve the desired reorientation of $R$ and $D$ if aid administrators would involve scientists more closely and directly in formulating policies and projects for bilateral aid, and if scientists in their turn took more interest and developed closer contacts with aid administration in their own country. The interest which many scientists, particularly younger scientists, show in problems of developing countries could be fostered and encouraged and perhaps more room could be found for problems of developing countries in the teaching and training curricula for scientists and technologists. Post-doctoral work

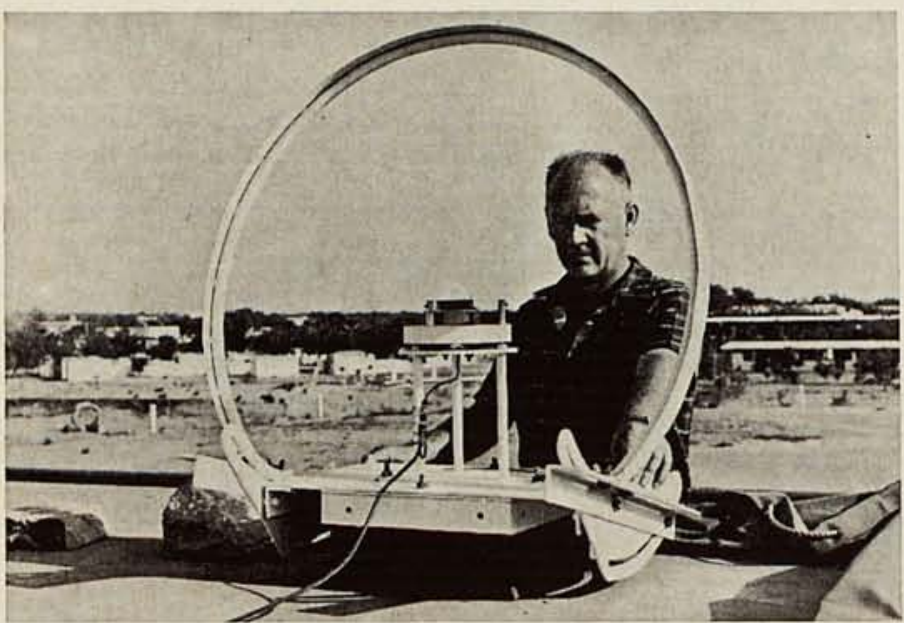

United Nations solar energy expert works with instrumentation for measurement of diffusion the sun's rays at the Solar Research Centre, Niamey, Nigeria.

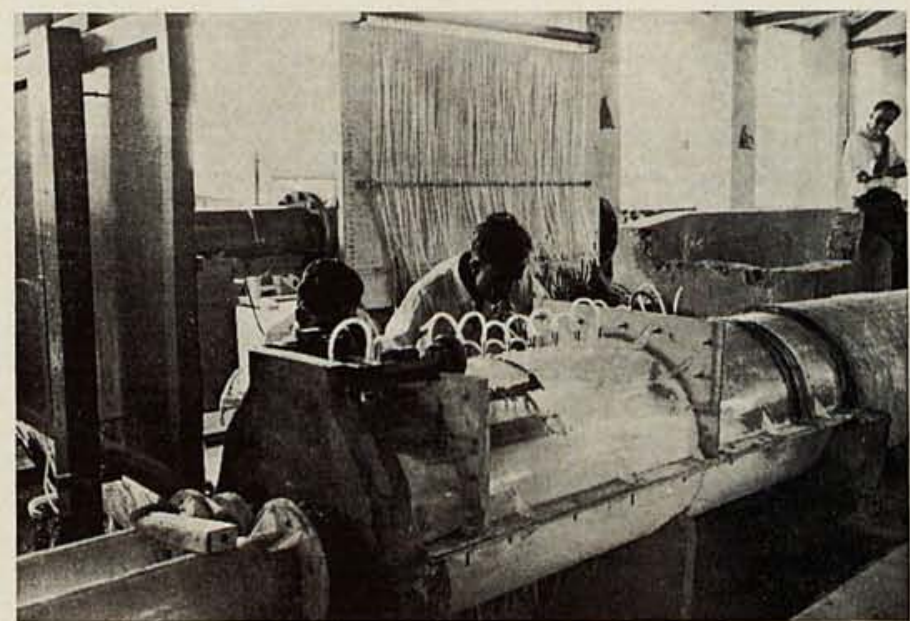

The study of values in cavitation research at the Central Water and Power Research Station, Poona, India is assisted by the UN Development Programme. 
in developing countries as well as doctoral work on problems of interest to developing countries could be financed and encouraged and the status of such work raised by enlarging the facilities for publication or discussion of the results of such work. Universities or other institutions in advanced countries could give their scientists sabbatical leave on full salary or half salary for work in developing countries, and could safeguard their career prospects and other privileges during their absence. Private multinational corporations often have highly trained staff suitable for work on problems of special interest to developing countries and often with field experience in developing countries, and these could be made available for such work, directly through bilateral or multilateral aid arrangements. Retired senior $R$ and $D$ staff from private companies might form a particularly valuable reservoir for work in developing countries. Foundations which have already played such a crucial part in solving major scientific and technological problems related to development could be strengthened by suitable means. The proposal has been made that a World Science Foundation be created which would award a series of incentive or challenge grants to enabje selected scientific institutions in developed countries to supplement their staffs for the purpose of increasing their capacity to attack programmes or support research for the benefit of developing countries.

\section{Follow-up action in Europe}

After publication of the World Plan of Action, two important events have been the Joint Meeting of European scientists and research directors with the UN Advisory Committee (Geneva, 19-20 November 1971), and the International Symposium on Targets for Scientific and Technological Development (Baden-bei-Wien, May 1972). The Geneva meeting recommended how research and development organizations in developed countries, particularly Europe, could help find solutions to problems in developing countries.

Mainly on the basis of a very detailed report on military $R$ and $D$ expenditure in developed countries, prepared for this purpose by the Swedish Institute for International Affairs, the Symposium at Baden-beiWien adopted unanimously the following resolution with regard to Target III of the World Plan :

The proposed shift in research orientation in developed countries is eminently desirable. Moreover, development needs might well justify that Target III be based on total $R$ and $D$ expenditures rather than on internal non-military $R$ and $D$ expenditures, and that such a transition might be reached by the end of the Second United Nations Development Decade. This objective should be made a part of national science policies.

\section{Conclusions}

In view of strong emphasis that the UN Advisory Committee for the Application of Science and Technology to Development places on the active support of the international scientific community, European physicists might well wish to consider how they can assist. The UN Advisory Committee will be happy to advise on courses of action, and will also be pleased to receive suggestions and offers of help. For further information, please contact Mr. G.B. Gresford, United Nations, New York or Mr. H. Einhaus, United Nations, Geneva.

\section{Publications}

1 World Plan of Action (United Nations, New York, 1971)

2 CLARKE, R. The Great Experiment (United Nations, New York, 1971)

3 MORAVCSIK, M.J., Physics in the developing countries, Physics Today 259 (September 1972) 40-43, 46, 47

\section{Letter to the Editor}

\section{Physics, Society and the Future}

At the Plenary Discussion on Physics and Society held on the evening prior to the General Assembly Meeting at Wiesbaden, I made the following points :

(i) EPS should act as a centre of information and critical analysis on matters of policy and planning in the realm of physics in Europe and beyond ;

(ii) EPS should provide a forum for the dispassionate assessment of the environmental crisis, the various plans to meet it and the role of physics and physicists in the pattern of Society as it is variously envisaged to develop.

There is now wide agreement that planning of research in physics, whether pure or applied, is vital in the interests of Society as a whole. This is indeed one of the trends which was brought out in the Conference. Physicists at large will accept, will have to accept, the "new role for scientists", to quote from an interview with L. Kowarski reported in the September 1972 Europhysics News "... to blend their scientific activity with social purpose by working as scientists in the urgent areas identified by the policy makers". They will accept this role all the more eagerly if they can be made to feel a sense of involvement in the policy making.

What is wanted and what I feel could be done in an objective and effective manner under the auspices of EPS, as a body sufficiently detached from the centres of decision making, is a regular and systematic review of science policies and priorities on a European scale which will allow the individual physicist in research, development or teaching to adjust his programme or direction of work to fit in with these policies.

It was the strong feeling on this issue, expressed mainly by the younger members who see a job crisis looming over the Atlantic horizon, which decided me to take the matter to the General Assembly in the form of a hurriedly composed "motion" (see page 6).

Encouraged by the sympathetic interest in my second point at the Plenary Discussion regarding the environ- mental crisis and the future of Society, $I$ added a second motion (even more hurriedly and imperfectly drafted). These are indeed big issues which should concern us primarily as members of Society rather than as professional specialists. However many of us are suspicious of political action in any shape or form, highly motivated as it may be, and are reluctant even to contemplate the serious commitment which joining the SSRS (Society for Social Responsibility in Science), or any of the increasing number of environmental or conservationist movements involves, without first knowing much more about it and hearing and working through all sides of the argument. This I feel can best be done among ourselves with the assistance of, or guidance by, colleagues from the environmental or social sciences.

I may be forgiven for ending with the old doggerel "Tempora mutantur nos et mutamur in illis". Times are indeed changing at an alarming pace. Let us progress from the Latin passive with its fatalistic ring : Let us do everything to change ourselves inside and outside EPS !

E.E. Schneider, School of Physics, University of Newcastle-upon-Tyne, England 